\title{
Profile changes in premolar extraction
}

\section{Alterações no perfil em extrações de pré-molares}

\begin{abstract}
Purpose: This retrospective study assessed patients treated with extraction of premolars by analysis of lateral cephalograms, comparing the effect of different tooth extraction protocols on the profile.

Methods: Eighty-seven patients were selected from the private practices of three orthodontists certified by the Brazilian Board of Orthodontics and Facial Orthopedics. These patients were treated with fixed edgewise appliances and divided into three groups according to the sequence in which premolars were extracted: "Group 40", maxillary first premolars (22 patients); "Group 44 ", both maxillary and mandibular first premolars (43 patients); and "Group 45", maxillary first and mandibular second premolars (22 patients). The $\mathrm{Z}$ angle and the Burstone line were used to quantify and compare the profiles before and after treatment.

Results: Student's t-test showed profile improvement in all groups, as the $Z$ angle value was higher at treatment completion and the lip measurements were in agreement with the values recommended by Burstone. Analysis of treatment changes by the ANOVA did not reveal significant differences between groups.

Conclusion: The protocols produced similar facial appearance at treatment completion.
\end{abstract}

Key words: Dental extraction; premolar tooth; corrective orthodontics

\section{Resumo}

Objetivo: Este estudo retrospectivo avaliou pacientes tratados com exodontias de pré-molares através da análise de telerradiografias, comparando o efeito de diferentes protocolos de exodontias no perfil.

Metodologia: 87 pacientes foram selecionados da clínica particular de três ortodontistas diplomados pelo Board Brasileiro de Ortodontia e Ortopedia Facial. Estes pacientes foram tratados com aparelho fixo Edgewise e foram divididos em três grupos, de acordo com a sequência de pré-molares extraídos: "Grupo 40", primeiros pré-molares superiores (22 pacientes); "Grupo 44", quatro primeiros pré-molares (43 pacientes); e "Grupo 45", primeiros pré-molares superiores e segundos inferiores (22 pacientes). $O$ Ângulo $Z$ e a Linha de Burstone foram utilizados para quantificar e comparar os perfis antes e após o tratamento.

Resultados: $O$ teste t-student mostrou melhora no perfil em todos os grupos, visto que o valor do ângulo $Z$ apresentou-se maior ao final do tratamento e as medidas dos lábios vieram ao encontro dos valores preconizados por Burstone. A análise das mudanças proporcionadas pelo tratamento pela ANOVA não revelou diferenças significativas entre os grupos

Conclusão: Os protocolos produzem aparências faciais semelhantes ao final do tratamento.

Palavras-chave: Extração dentária; dente pré-molar; ortodontia corretiva

\author{
Susiane Allgayer a \\ Eduardo M. Santayana de Lima a \\ Susana Deon Rizzatto a \\ Carlos Alberto Estevanell Tavares ${ }^{b}$ \\ Luciane Macedo de Menezes a \\ Mauricio Barbieri Mezzomo a
}

\author{
- Department of Orthodontics, Pontifícia Uni- \\ versidade Católica do Rio Grande do Sul, Porto \\ Alegre, RS, Brazil \\ b Department of Orthodontics, ABO, Porto Alegre, \\ RS, Brazil
}

\author{
Correspondence: \\ Susiane Allgayer \\ Faculdade de Odontologia - PUCRS \\ Av. Ipiranga,6681 - Prédio 06 - Sala 209 \\ Porto Alegre, RS - Brazil \\ 90619-900 \\ E-mail: susianeallgayer@gmail.com \\ E-mail: susianeallgayer@ibest.com.br
}

Received: March 19, 2011

Accepted: November 15, 2011

Conflict of Interest: The authors state that there are no financial and personal conflicts of interest that could have inappropriately influenced their work.

Copyright: (C) 2011 Allgayer et al.; licensee EDIPUCRS. This is an Open Access article distributed under the terms of the Creative Commons AttributionNoncommercial-No Derivative Works 3.0 Unported License. 


\section{Introduction}

Most orthodontic patients have some shortage of space or crowding. Although non-extraction treatment has become popular during the last decade, in such cases extractions may often be needed for a favorable treatment outcome (1-3).

The study of beauty and facial harmony has been the focus of orthodontic practice for several years (4). The improvement in facial esthetics is one of the main reasons behind the interest of patients in orthodontic treatment. Malocclusions may cause functional, esthetic and psychological problems of variable extent, depending on their relationship with the soft tissues (1-3). Therefore, assessing changes in the soft tissue profile that result from orthodontic movement has been the goal of several studies (5).

Additionally, assessment of the profile is a constant continuous process of study during the life of orthodontists (6) and students that aim to practice this specialty. These professionals must be aware of the technique and achieve experience on the effects of tooth extraction on the esthetics and profile of their patients.

Merrifield (7), studying facial profiles, developed the $\mathrm{Z}$ angle to quantify the balance of the lower facial third. The $\mathrm{Z}$ angle is formed by intersection of the Frankfurt horizontal plane and the line tangential to the soft tissue chin and the most protruded lip. Merrifield established that for an adult with normal FMA, IMPA, FMIA, and ANB angles, a normal $\mathrm{Z}$ angle would be $80^{\circ}$. For patients aged between 11 and 15 years, a normal $\mathrm{Z}$ angle would be $78^{\circ}$.

Burstone published a study on the analysis of soft tissues of patients who required orthognathic surgery and measured the anteroposterior position of the lip from a line that goes from the subnasal area to the soft tissue pogonion (8). The author selected the line that goes from the subnasal to the soft tissue pogonion as reference because it is a plane with minimal variation in the face and is not influenced by nasal growth, which shows great variability (8).

The $\mathrm{Z}$ angle and the Burstone's E line were chosen due to their easy and accurate measurement $(5,10)$ and relevance regarding lip positioning and changes, making them excellent diagnostic guidelines (7). With all this in mind, this study tested the following null hypothesis: there is no difference in the soft tissues after treatment with extraction of two mandibular first or mandibular second premolars (11).

\section{Methods}

The sample was retrospectively selected from the private practice of three orthodontists certified by the Brazilian Board of Orthodontics and Dentofacial Orthopedics (BBO). The initial (T1) and final (T2) lateral cephalograms of 87 patients orthodontically treated with fixed edgewise appliances were divided into three groups. The mean age was 15 years old (range 11-18 years), with 31 boys and 56 girls. The treatment time was 3 years (range 2-5 years).

The tooth extraction protocols were: "Group 40" (G40), maxillary first premolars (22 patients); “Group 44” (G44), maxillary and mandibular first premolars (43 patients); and "Group 45" (G45), maxillary first premolars and mandibular second premolars (22 patients). Group 40 was selected as the control group.

Additional inclusion criteria for this study were: 1 - all patients had their premolars extracted as part of their predetermined treatment plan (12,13); 2 - all patients were Caucasoid, without congenitally missing teeth or previous extractions (14); 3 - all permanent teeth were present up to the second molars (15); 4 - good quality of pre- and posttreatment radiographs, taken with the lips relaxed, teeth in occlusion, and using the same cephalostat $(11,16)$; 5 - no prior use of functional appliance $(12,13,14,17)$ or orthognathic surgery (14) between the two radiographs; 6 - fully closed gaps at treatment completion (17); 7 - gaps closed with $0.019 \times 0.025$ stainless steel arches (17); and 8 - where possible, maintenance of intercanine and intermolar distances (17).

The radiographs were taken in centric occlusion, a technique devised by Broadbent (19), with the lips at rest as defined by Burstone (19). Cephalometric tracings were performed manually by the same investigator and digitized. Data were analyzed with Dentofacial Planner software (version 2.0 Toronto, Ontario, Canada) (15), imported into Excel (Microsoft, Redmond, Wash.) for initial handling, and then evaluated with SPSS (version 10.0, SPSS Inc. Chicago, III, USA). The selected measurements were the Z angle defined by Merrifield (7) (Fig. 1) and the Burstone's E line (8) (Fig. 2).

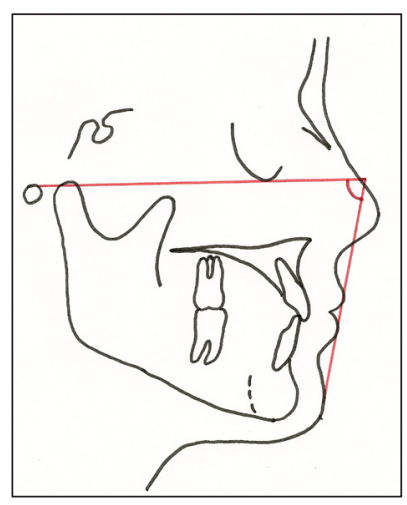

Fig. 1. Z angle measurement.

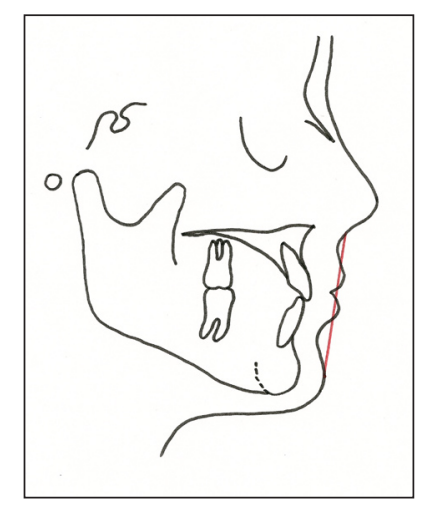

Fig. 2. E line measurement.

\section{Error Assessment}

To assess the intraexaminer error regarding the cephalometric tracing, 30 lateral cephalograms were randomly selected and retraced after a 3-week interval. The agreement between the first and second measurements was assessed by the Student's t test for paired samples at a 5\% significance level. None of the measurements presented significant differences, which confirmed the calibration of the examiner. 


\section{Comparative Analysis Between Study Groups}

The changes from $\mathrm{T} 1$ to $\mathrm{T} 2$ were evaluated to determine statistically significant variations that occurred separately in each group (G40, G44, G45).

\section{Statistical Analysis}

The normality of data was verified by the nonparametric Kolmogorov-Smirnov test, which is regarded as a proof of adherence. The Kolmogorov-Smirnov test concerns the degree of agreement between the distribution of a set of sample values and a particular theoretical distribution. In the present study, this theoretical distribution was the normal distribution. The measurements collected in this study conformed to a normal distribution, so parametric tests were applied.

The initial (T1) and follow-up (T2) measurements of the study sample was analyzed by the Student's t-test to compare means of paired samples. For comparison between groups we used analysis of variance (ANOVA) because the same individuals were measured in multiple situations.
The results were considered statistically significant at a level of $5 \%(P \leq 0.05)$. Data were processed and analyzed on the SPSS version 10.0 .

\section{Results}

\section{Intragroup Analysis (Table 1)}

According to the results of Student's t-test for paired samples, the $\mathrm{Z}$ angle measurement showed significant increase at T2 over T1. The Ls (upper lip) and Li (lower lip) measurements showed a significant reduction at $\mathrm{T} 2$.

Intergroup Analysis of Incremental Changes (Table 2)

According to the ANOVA test, none of the measurements presented significant differences between the study groups.

Intergroup Analysis of Absolute Dimensions (Table 3, 4)

According to the results of the ANOVA test, only the Li measurement showed significant difference between groups at $\mathrm{T} 1$. We observed that G44 had significantly higher values than G40. At T2, the results of the ANOVA test indicated no significant difference between groups.

Table 1. Results of the comparison between the times $T 2$ and $T 1$.

\begin{tabular}{|c|c|c|c|c|c|c|c|}
\hline \multirow{2}{*}{ Measurement } & \multicolumn{2}{|c|}{$\begin{array}{l}\text { Pretreatment } \\
\text { (T1) }\end{array}$} & \multicolumn{2}{|c|}{$\begin{array}{l}\text { Posttreatment } \\
\text { (T2) }\end{array}$} & \multicolumn{2}{|c|}{$\begin{array}{l}\text { Difference } \\
\text { (T2-T1) }\end{array}$} & \multirow[t]{2}{*}{$P$} \\
\hline & Mean & SD & Mean & SD & Mean & SD & \\
\hline \multicolumn{8}{|l|}{ Group $40(n=22)$} \\
\hline$Z$ angle & 67.61 & 8.31 & 72.09 & 7.70 & 4.48 & 3.49 & $0.000^{*}$ \\
\hline Ls to $\left(\mathrm{Sn}-\mathrm{Pg}^{\prime}\right)$ & 5.66 & 2.61 & 3.78 & 2.16 & -1.89 & 1.70 & $0.000^{*}$ \\
\hline Li to $\left(\mathrm{Sn}-\mathrm{Pg}^{\prime}\right)$ & 3.60 & 3.25 & 2.31 & 2.60 & -1.29 & 1.68 & $0.002 *$ \\
\hline \multicolumn{8}{|l|}{ Group $44(n=43)$} \\
\hline$Z$ angle & 66.27 & 8.50 & 72.30 & 7.30 & 6.03 & 5.98 & $0.000^{*}$ \\
\hline Ls to $\left(\mathrm{Sn}-\mathrm{Pg}^{\prime}\right)$ & 5.33 & 2.11 & 3.27 & 1.98 & -2.05 & 1.96 & $0.000^{*}$ \\
\hline Li to $\left(\mathrm{Sn}-\mathrm{Pg}^{\prime}\right)$ & 5.52 & 2.76 & 3.19 & 2.28 & -2.33 & 2.15 & $0.000^{*}$ \\
\hline \multicolumn{8}{|l|}{ Group $45(n=22)$} \\
\hline$Z$ angle & 71.37 & 7.11 & 76.24 & 5.77 & 4.86 & 5.38 & $0.000^{*}$ \\
\hline Ls to $\left(\mathrm{Sn}-\mathrm{Pg}^{\prime}\right)$ & 4.60 & 1.56 & 2.74 & 1.86 & -1.85 & 1.35 & $0.000^{*}$ \\
\hline Li to $\left(\mathrm{Sn}-\mathrm{Pg}^{\prime}\right)$ & 4.20 & 2.23 & 2.15 & 1.76 & -2.05 & 1.93 & $0.000^{*}$ \\
\hline
\end{tabular}

* Significant difference, $P \leq 05$

Table 2. Comparison of the T2-T1 differences among the study groups (incremental changes between groups).

\begin{tabular}{llcccc}
\hline Measurement & Group & $\mathbf{n}$ & Mean & SD & $P$ \\
\hline Z angle & Group 40 & 22 & 4.48 & 3.49 & 0.090 \\
& Group 44 & 43 & 6.03 & 5.98 & \\
& Group 45 & 22 & 4.86 & 5.38 & \\
Ls to $\left(\mathrm{Sn}^{-} \mathrm{Pg}^{\prime}\right)$ & Group 40 & 22 & -1.89 & 1.70 & 0.887 \\
& Group 44 & 43 & -2.05 & 1.96 & \\
& Group 45 & 22 & -1.85 & 1.35 & \\
Li to $\left(\mathrm{Sn}-\mathrm{Pg}^{\prime}\right)$ & Group 40 & 22 & -1.29 & 1.68 & 0.140 \\
& Group 44 & 43 & -2.33 & 2.15 & \\
& Group 45 & 22 & -2.05 & 1.93 & \\
\hline
\end{tabular}

* Significant difference, $P \leq .05$
Table 3. Comparison of $\mathrm{T} 1$ measurements among the groups (Intergroup Analysis of the Absolute Dimensions).

\begin{tabular}{lccccc}
\hline Measurement & Group & $\mathbf{n}$ & Mean & SD & $P$ \\
\hline Z angle & Grup 40 & 22 & 67.61 & 8.31 & 0.061 \\
& Grup 44 & 43 & 66.27 & 8.50 & \\
& Grup 45 & 22 & 71.37 & 7.11 & \\
Ls to $\left({\left.\mathrm{Sn}-\mathrm{Pg}^{\prime}\right)}^{\text {Grup 40 }}\right.$ & 22 & 5.66 & 2.61 & 0.233 \\
& Grup 44 & 43 & 5.33 & 2.11 & \\
& Grup 45 & 22 & 4.60 & 1.56 & \\
Li to $($ Sn-Pg') & Grup 40 & 22 & $3.60^{\mathrm{A}}$ & 3.25 & 0.023 \\
& Grup 44 & 43 & $5.52^{\mathrm{B}}$ & 2.76 & \\
& Grup 45 & 22 & $4.20^{\mathrm{AB}}$ & 2.23 & \\
\hline
\end{tabular}

* Significant difference, $P \leq .05$ 
Table 4. Comparison of the T2 measurements among the groups.

\begin{tabular}{lccccc}
\hline Measurement & Group & $\mathrm{n}$ & Mean & SD & $P$ \\
\hline Z-angle & Group 40 & 22 & 72.09 & 7.70 & 0.076 \\
& Group 44 & 43 & 72.30 & 7.30 & \\
& Group 45 & 22 & 76.24 & 5.77 & \\
Ls to $\left(\mathrm{Sn}-\mathrm{Pg}^{\prime}\right)$ & Group 40 & 22 & 3.78 & 2.16 & 0.233 \\
& Group 44 & 43 & 3.27 & 1.98 & \\
& Group 45 & 22 & 2.74 & 1.86 & \\
Li to $\left(\mathrm{Sn}-\mathrm{Pg}^{\prime}\right)$ & Group 40 & 22 & 2.31 & 2.60 & 0.142 \\
& Group 44 & 43 & 3.19 & 2.28 & \\
& Group 45 & 22 & 2.15 & 1.76 & \\
\hline
\end{tabular}

* Significant difference, $P \leq .05$

\section{Discussion}

The goal of several studies has been to establish a prognosis of changes that occur in patients' faces under the cumulative effect of growth, development, and orthodontic treatment (20). This work was conducted on patients in an active growth age as one of the inclusion criteria.

Merrifield (7) determined that for an adult with normal FMA, IMPA, and ANB FMIA angles, a normal Z Angle would be $80^{\circ}$. For patients aged between 11 and 15 years, the normal Z Angle would be $78^{\circ}$. The treatment to which these patients were submitted, i.e., treatment with "edgewise-type" appliance with tooth extraction protocols indicated for each malocclusion during the growth period, improved the facial profile appearance of all groups, as the $\mathrm{Z}$ angle final values were significantly higher than before treatment (Table 1).

According to Burstone (8), the anteroposterior position of the lip is evaluated by drawing a line from the subnasal to the soft pogonion; and the amount of protrusion and retraction of the lip is measured by the linear distance perpendicular to this line to the most prominent point of both lips. This author recommended that the upper lip should be $3 \mathrm{~mm}$ and the lower lip less than $2 \mathrm{~mm}$ for a harmonious anteroposterior position. Many factors involve the lip line, and it is obvious that the amount of protrusion can be controlled by various orthodontic and surgical procedures. A good position for the lip can be obtained by protruding incisors surgically or orthodontically, increasing or reducing the chin prominence, or both (8).

The orthodontic-surgical treatment is indicated when the dentofacial deformity or sagittal discrepancy between the dental arches is severe enough to indicate a surgery. Analysis of occlusion, cephalometric findings, facial analysis and dental casts are determinant to decide between orthodontic or orthodontic-surgical treatment (21). Patients ultimately decline surgery (22) to correct dental alignment problems (22). The surgery is costly and requires hospitalization, causing morbidity and job absenteeism, and the patient may feel that the malocclusion is not severe enough from esthetic and functional standpoints to justify the risks and costs of surgery (22-24).

With the nonsurgical treatment performed in the present study, the Student's t-test showed improvement in all groups, as both upper and lower lips decreased significantly in all three groups and were in agreement with the values recommended by Burstone. ANOVA showed that the differences between groups were not statistically significant, which does not corroborate the previous findings of Allgayer et al. (25), who found less lower lip retraction in the group with extraction of second premolars.

The post-treatment $Z$ angle values suggest that the profiles of groups became similar at treatment completion and the patients were benefited in their facial esthetics by the treatment indicated in the present study (Table 1). As James (6) stated, treating patients without extraction simply not to remove teeth or to simplify the treatment is not justified, because it is as wrong not to extract teeth when extraction is indicated as to extract when it is not indicated. Instead, the ideal approach is to apply the correct extraction protocol for each type of malocclusion. According to James (6), the most indicated combinations of premolar extractions according to the characteristics of malocclusion are:

- Characteristics of the extraction group of G40: 1 - class II dental relationship; 2 - maxillary protrusion, anterior crowding in the maxilla, or both; and 3 - good position of mandibular incisors, with little or no crowding.

- Characteristics of the extraction group of G44: 1 - severe discrepancy in arch length, dental protrusion, bialveolar, or both; 2 - for class I or II dental relationship; and 3 - medium or high mandibular plane.

- Characteristics of the extraction group of G45: 1 - Class II dental relationship and average or moderate Class II malocclusion; 2 - average or moderate discrepancy in arch length; 3 - disharmony in the soft tissues; and 4 - medium or high mandibular plane angle (6).

Before undergoing treatment, G44 had the highest protrusion, with a $\mathrm{Z}$ angle of $66^{\circ}$, i.e., the worst profile, followed by G40 with $67^{\circ}$ and finally G45, with less compromised profile, with a $\mathrm{Z}$ angle of $71^{\circ}$ (Table 1). With this treatment the profiles improved and became more similar. Group 45 came closest to the recommended standard. It should be mentioned that the $\mathrm{Z}$ angle is a norm for the American population. This is in agreement with Cappeli (5), who reported similar findings, suggesting that the difference could be attributed to the variability among Caucasians assessed in that study and in the present study. The latter patients are white, but Brazilians, and thus carry all the genetic load of miscegenation that contributes to the characterization of the Brazilian facial type, which is predominately "fuller," that is more convex. A very straight profile, which is sought by and considered pleasant to Americans, can become extremely difficult to achieve and can also be considered unacceptable for a Brazilian.

Groups G40 and 44 showed more convex profiles at treatment completion than G45, which is consistent with findings of other authors who point out that the results are influenced by pretreatment characteristics $(4,6,11,12,16)$. As the incremental changes of all other variables were similar between the study groups, it may be suggested that treatment protocols produce equivalent results (Table 4). 
By their nature, retrospective studies present limitations of interpretation $(16,24)$ because the rationale on the diagnosis and treatment plan for each case may not be fully determined (16). This applies to samples treated by different professionals or an old time that does not represent the contemporary technique. To overcome these questions, the present study sample was selected from the practices of three professionals certified by the Board, in agreement with biomechanical principles (16).

Further research should be conducted to assess the correlation between incisor retraction and lip response in premolar extractions. Possible changes in the values of facial height index and its influence on the profile with these same protocols should be verified. A study should also be conducted to assess the facial changes of patients studied here yet in the long term, i.e., seeking to quantify the cumulative effect of orthodontic treatment and age on the facial profile.

\section{Conclusions}

The null hypothesis was accepted because the facial profile results after treatment with various extraction protocols was similar.
1. Changes in facial profiles of cases treated with the studied extraction protocols were favorable when quantified by $\mathrm{Z}$ angle measures, as the posttreatment $\mathrm{Z}$ angle value showed statistically significant increase in all extraction groups.

2. There was no statistically significant difference between study groups at treatment completion.

3. Because the changes caused by treatment to all other variables were similar between the study groups, we concluded that the treatment protocols produced similar results in this type of patient.

\section{Acknowledgments}

This article is derived from the study used for partial fulfillment of the first author's requirements for the master of science degree in Orthodontics at Pontifícia Universidade Católica do Rio Grande do Sul. The authors would like to acknowledge the role of Dr. Carlos Alberto Estevanell Tavares, Eduardo Martinelli Santayana de Lima and Susana Deon Rizzatto in the diagnosis, planning and treatment of the patients.
References
1. Iseri H, Kisnisci R, Bzizi N, Tuz H. Rapid canine retraction and orthodontic treatment with dentoalveolar distraction osteogenesis. Am J Orthod Dentofacial Orthop 2005;127: 533-41.

2. Prado SR, Souza MMG, Lira ALS. Tratamento da maloclusão de Classe Il com a extração de 4 premolares superiores: Relato de caso. Orthodontic Science and Practice 2011;4: 661-67.

3. Lima EMS, Farret MM, Araúio LL. Tratamento Ortodôntico-cirúrgico da má-Oclusão de Classe III: relato de caso. Rev Clín Ortodon Dental Press 2010;8:61-70.

4. Bishara SE, Cummins DM, Jakobsen JR, Zaher AR. Dentofacial and soft tissue changes in Class II, Division 1 cases treated with and without extractions. Am J Orthod Dentofacial Orthop 1995; 107:28-37.

5. Capelli JJ, Tibana RH. Alterações no perfil facial em indivíduos submetidos a tratamento ortodôntico com extrações de quatro pré-molares. Ortodontia Gaúcha 2002;6:35-45.

6. James RD. A comparative study of facial profiles in extraction and nonextraction treatment. Am J Orthod Dentofacial Orthop 1998;1 14:265-76.

7. Merrifield LL. The profile line as an aid in critically evaluating facial esthetics. Am J Orthod 1966;52:804-22.

8. Leagan HL, Burstone CJ, Conn F. Soft tissue cephalometric analysis for orthognatic surgery. Journal of Oral Surgery 1980;38:744-51.

9. Oliver BM. The infuence of lip thickness and strain on upper lip response to incisor retraction. Am J Orthod 1982;82:141-9.

10. Miloševic' SA, Lapter-Varga M, Šlaj M. Analysis of the soft tissue facial profile By means of angular measurements. Eur J Orthod 2008;30:135-40.

11. Wholley C J, Woods MG. The effects of commonly prescribed premolar Extraction sequences on the curvature of the upper and lower lips. Angle Orthod 2003;73:386-395.

12. Ong HB, Woods MG. An occlusal and cephalometric analysis of maxillary first and second premolar extraction effects. Angle Orthod 2001;71:90-102.

13. Shearn BN, Woods MG. An occlusal and cephalometric analysis of lower first and second premolar extraction effects. Am J Orthod Denfacial Orthop 2000; 117:351-61.

14. Basciftci FA, Uysal T, Buyukerkmen A, Demir A. The influence of extraction treatment on Holdaway soft-tissue measurements. Angle Orthod 2004;74:167-73.

15. Janson G, Fuziy A, Freitas MR, Henriques JFC, Almeida RR. Soft-tissue treatment changes in Classe II Divison 1 maloclusion with and without extractions of maxillary premolars. Am J Orthod Dentofacial Orthop 2007;132:729.e1-729.e8. 
16. Moseling KP, Woods MG. Lip curve changes in females with premolar extraction or nonextraction treatment. Angle Orthod 2004;74:51-62.

17. Al-Nimri KS. Changes in mandibular incisor position in Classe II Division 1 malocclusion treated with premolar extractions. Am J Orthod Dentofacial Orthop 2003;124: 708-13.

18. Broadbent $\mathrm{BH}$. A new $\mathrm{x}$-ray technique and its application to orthodontia. Angle Orthod $1931 ; 1: 45-66$.

19. Burstone CJ. Lip posture and its significance in treatment planning. Am J Orthod 1967;53:262-284.

20. Hershey HG. Incisor tooth retraction and subsequent profile change in postadolescent female patients. Am J Orthod 1972;61:45-54.

21. Arnett GW, Gunson MJ. Facial planning for orthodontists and oral Surgeons. Am J Orthod Dentofacial Orthop 2004;126:290-5.

22. Handelman CS. Nonsurgical rapid maxillary alveolar expansion in adults: A clinical evaluation. Angle Orthod 1997;67:291-308.

23. Capelozza Filho L, Cardoso Neto J, da Silva Filho OG, Ursi WJ. Non-surgically assisted rapid maxillary expansion in adults. Int J Adult Orthodon Orthognath Surg 1996;1 1: 57-66.

24. Handelman CS, Wang L, BeGole EA, Haas AJ. Nonsurgical rapid maxillary expansion in adults: Report on 47 cases using the Haas expander. Angle Orthod 2000;70:129-44.

25. Allgayer S, de Lima EMS, Mezomo MB. Influence of premolar extractions on the facial profile evaluated by the Holdaway analysis. Rev Odonto Cienc 2011 ;26:22-9. 